INKLUSIF Vol 3. No. 2 Desember 2018

\title{
PERBANDINGAN ANTARA RETURN SAHAM SYARIAH DAN SAHAM KONVENSIONAL DI BURSA EFEK INDONESIA (PENDEKATAN VEKTOR ERROR CORRECTION MODEL)
}

\author{
Qoonitah Fithri Al-Nisa ${ }^{1}$ \\ Email: qoonitahfithrialnisa@gmail.com
}

\begin{abstract}
Average growth of sharia stock transaction volume is $167.2 \%$ compared to $130 \%$ non-sharia. In terms of the average growth in the value of Islamic stock transactions in the last five years reached $70.7 \%$ compared to $25.4 \%$ non-sharia. While the average frequency growth reaches $185.7 \%$ compared to $160.7 \%$ non-sharia. The description of the average value of JII sharia stock returns and the $\mathrm{JCl}$ conventional stock return value resulted in the average $\mathrm{JII}$ index yield far better than the $\mathrm{JCl}$ return.

In the short term there are underpricing phenomena and in the long run there is a decrease in performance (underperformance). Determination of whether or not the performance of the stock, both short and long term is seen from the amount of abnormal return. If abnormal return $>0$, shows performance that is outperformed (good), on the contrary if abnormal return $<0$ is underperfomed (bad).

If we look at the results of long-term and short-term analysis, the potential of the Islamic capital market is considered good and will still experience growth. This is evident from the return of the JII index which is better than the $\mathrm{JCl}$ index.
\end{abstract}

Keywords: Return, JII, IHSG

\section{ABSTRAK}

Rata-rata pertumbuhan volume transaksi saham syariah $167,2 \%$ berbanding $130 \%$ non syariah. Dari sisi rata-rata pertumbuhan nilai transaksi saham syariah dalam lima tahun terakhir mencapai $70,7 \%$ berbanding $25,4 \%$ non syariah. Sementara rata-rata pertumbuhan frekuensinya mencapai $185,7 \%$ berbanding 160,7\% non syariah. Deskripsi rata-rata nilai return saham syariah JII dan nilai return saham konvensional IHSG menghasilkan rata-rata hasil indeks JII jauh lebih baik dari return IHSG.

Dalam jangka pendek terdapat fenomena underpricing dan dalam jangka panjang terdapat penurunan kinerja (underperformance). Penentuan baik tidaknya kinerja saham, baik jangka pendek maupun jangka panjang dilihat dari besarnya return abnormal. Apabila return abnormal $>0$, menunjukkan kinerja yang outperformed (baik), sebaliknya apabila return abnormal $<0$ underperfomed (buruk).

Jika kita lihat hasil analisa jangka panjang maupun jangka pendek maka potensi pasar modal syariah dinilai baik dan masih akan mengalami pertumbuhan, hal ini terlihat dari hasil return indeks JII yang lebih baik dari indeks IHSG hal ini berhubungan dengan adanya kebijakan pemerintah yang membentuk Komite Nasional Keuangan Syariah (KNKS).

Kata Kunci : Return, JII, IHSG

\footnotetext{
${ }^{1}$ Mahasiswa Pascasarjana IAIN Syekh Nurjati Cirebon.
} 
INKLUSIF Vol 3. No. 2 Desember 2018

\section{PENDAHULUAN}

\section{A. Latar Belakang}

Investor dalam melakukan kegiatan investasi mempunyai beberapa tujuan yang ingin dicapai, yaitu: terciptanya keberlanjutan (continuity) dalam investasi, profit maksimum atau keuntungan yang diharapkan (profit actual), kemakmuran bagi para pemegang saham, dan turut memberikan andil bagi pembangunan bangsa. ${ }^{2}$

Jakarta Islamic Index (JII) suatu indeks saham yang juga diperdagangkan dalam BEI. Saham-saham yang diikut sertakan dalam perdagangan diperlakukan menggunakan prinsip syariah. Jakarta Islamic Index digunakan sebagai tolok ukur (benchmark) untuk mengukur kinerja investasi pada saham dengan basis syariah. Nilai indeks JII dapat meningkatkan kepercayaan investor untuk mengembangkan investasi dalam ekuitas secara syariah. Saham syariah JII terdiri dari 30 saham yang paling likuid dan memiliki kapitalisasi pasar yang besar.

Indeks Harga Saham Gabungan (IHSG) merupakan indeks yang digunakan untuk melihat perubahan harga saham secara keseluruhan di pasar. Kenaikan dan penurunan harga saham di bursa dapat dilihat dari penurunan dan kenaikan IHSG. Return saham pada umumnya menjadi indikator terpenting seorang investor dalam mengambil keputusan dalam berinvestasi. Tingkat return saham yang berbeda dimana return digambarkan melalui kinerja indeks perusahaan melalui indeks harga yang dikeluarkan yang berubah-ubah pada setiap harinya. ${ }^{3}$ Dalam penelitian lainnya menjelaskan bahwa kinerja indeks saham syariah lebih tinggi jika dibandingkan dengan saham-saham non syariah. ${ }^{4}$

Laporan transaksi saham mencatat, pertumbuhan volume transaksi saham syariah $167,2 \%$ berbanding $130 \%$ non syariah. Dari sisi pertumbuhan nilai transaksi saham syariah dalam lima tahun terakhir mencapai $70,7 \%$ berbanding $25,4 \%$ non syariah. Sementara rata-rata pertumbuhan frekuensinya mencapai $185,7 \%$ berbanding $160,7 \%$ non syariah. Laporan indeks saham konvensional mencatat return $1,08 \%$, dan saham syariah mencatat $0,53 \%$ dalam sepekan. Hal tersebut tidak selaras dengan laporan tingkat return saham syariah yang lebih kecil dibanding return saham konvensional. Pergerakan indeks akan menunjukkan perubahan situasi pasar yang terjadi, sehingga dijadikan barometer kesehatan ekonomi di suatu Negara dan juga sebagai landasan analisis statistik pasar terakhir. Fenomena ekonomi tersebut meliputi mikro dan makro ekonomi. Fenomena makro ekonomi diantaranya perubahan nilai tukar, suku bunga, tingkat inflasi.

Hasil data keseluruhan rata-rata pertumbuhan indeks saham menjelaskan saham syariah lebih besar dibanding saham konvensional. Kajian yang dilakukan oleh Asadimitra ${ }^{5}$ menerangkan kinerja indeks syariah lebih baik dibandingkan kinerja indeks konvensional.

\footnotetext{
${ }^{2}$ Irham Fahmi, Teori Portofolio Dan Analisis Investing (Bandung: Alfabeta, 2009). 23.

${ }^{3}$ Rob Bauer, Rogér Otten, and Alireza Tourani Rad, 'Ethical Investing in Australia: Is There a Financial Penalty?', Pacific Basin Finance Journal, 14.1 (2006), 33-48 <https://doi.org/10.1016/j.pacfin.2004.12.004>.

${ }^{4}$ Fadillah Mansor and M Ishaq Bhatti, 'Risk and Return Analysis on Performance of the Islamic Mutual Funds : Evidence from Malaysia', Global Economy and Finance Journal, 4.1 (2011), 19-31.

${ }^{5}$ Rizki Dwi Kurniawan and Nadia Asandimitra, 'Analisis Perbandingan Kinerja Indeks Saham Syariah Dan Kinerja Indeks Saham Konvensional', Jurnal Ilmu Manajemen, 2 (4).Oktober 2014 (2014), 1356-66.
} 
Sedangkan dalam penelitan yang dilakukan oleh Hussein ${ }^{6}$, dan Wimmer ${ }^{7}$ menerangkan bahwa tidak ada perbedaan kinerja secara signifikan antara indeks saham syariah dan indeks saham konvensional. Ashar ${ }^{8}$ mengindikasikan bahwa kriteria seleksi yang dilakukan oleh OJK terhadap saham-saham pada IHSG yang masuk dalam daftar JII tidak memberikan pengaruh terhadap performa JII.

Kesimpulan yang didapat apa yang telah diteliti mereka masih terdapat perbedaan hasil kinerja indeks pada masing-masing indeks saham yang berbeda tentang return saham. Oleh karna itu dalam penelitian ini akan meneliti tentang perbedaan tingkat retun saham syariah dan saham konvensional. Return saham syariah akan diwakilkan oleh indeks JII dan saham syariah oleh indeks IHSG.

\section{B. Metode Penelitian}

Penelitian ini menggunakan metode kuantitatif dengan didukung dengan analisis statistik deskriptif. Penelitian ini merupakan studi kausal komparatif yaitu penelitian yang menunjukkan arah hubungan antara variabel bebas dengan variabel terikat, disamping mengukur kekuatan hubungannya. Penelitian ini menggunakan data sekunder, yaitu data harian return saham syariah dan saham konvensional pada bursa efek Indonesia periode 5 tahun, yaitu tahun 2012 sampai dengan 2017.

Untuk menguji hipotesis kausalitas antara saham syariah dan saham konvensional pada return tradeoff maka digunakan metode uji kausalitas Granger setelah dipastikan bahwa data yang diuji sudah stasioner karena uji Granger didasarkan pada asumsi stasioneritas. Data yang stasioner adalah data yang residualnya bersifat white noise, yaitu residualnya memiliki rataan nol, ragam konstan dan tidak ada korelasi diantara dependent variable. Pengujian stasioneritas akan dilakukan dengan metode uji statistik Augmented Dickey-Fuller (ADF).

VAR VECM adalah model analisi ekonomatrika yang dapat digunakan untuk mengetahui tingkah laku jangka pendek dari suatu variabel terhadap jangka panjangnya, akibat adanya shock yang permanen. Untuk menganalisis hasil regresi dengan metode VAR atau VAR VECM akan digunakan Impulse Response Function (IRF) dan Variance Decomposition (VDC). Metode IRF dan VDC adalah metode yang banyak digunakan peneliti karena dapat lebih baik dalam menggambarkan respon dari suatu shock melalui grafik dan tabel dalam suatu periode lag. ${ }^{9}$

\footnotetext{
${ }^{6}$ Khaled A. Hussein, 'Ethical Investment: Empirical Evidence From FTSE Islamic Index', Islamic Economic Studies, 12.1 (2004), 21-40 <https://doi.org/10.3905/joi.2005.580557>.

${ }^{7}$ Sabastian Utz and Maximillian Wimmer, 'Are They Any Good at All? A Financial and Ethical Analysis of Socially Responsible Mutual Funds', Journal of Asset Management, 15.1 (2014), 72-82 <https://doi.org/10.1057/jam.2014.8>.

${ }^{8} \mathrm{SH}$ Ashraf and D Sharma, 'Performance Evaluation of Indian Equity Mutual Funds against Established Benchmarks Index', Int J Account Res, 2.1 (2014), 1-7 <https://doi.org/10.4172/ijar.1000113>.

${ }^{9}$ Sochrul R Ajija, Cara Cerdas Menguasai Eviews (Jakarta: Salemba Empat, 2011). 18.
} 
INKLUSIF Vol 3. No. 2 Desember 2018

\section{PEMBAHASAN}

\section{A. Landasan Teori}

Semenjak dikembangkannya pasar modal syariah yang mulai dirintis dengan diluncurkannya indeks harga saham JII berdasarkan prinsip syariah pada tanggal 3 Juli tahun 2000 dan Fatwa MUI mengenai diperbolehkannya investasi saham, maka berarti supply dan demand yang terbentuk di Bursa Efek Jakarta (BEJ) bukan hanya diprakarsai oleh emiten dan investor non-muslim saja, tetapi diprakarsai juga oleh emiten dan investor muslim yang berpegang teguh pada prinsip syariah dan hukum negara.

Harga saham di pasar modal Indonesia dapat saja dipengaruhi oleh kebijakankebijakan yang ada pada prinsip syariah dan hukum negara tersebut. Keberadaan pasar modal di Indonesia merupakan salah satu faktor terpenting dalam ikut membangun perekonomian nasional, terbukti telah banyak industri dan perusahaan yang menggunakan institusi pasar modal ini sebagai media untuk menyerap investasi dan media untuk memperkuat posisi keuangannya. Secara faktual, pasar modal telah menjadi financial nerve centre (saraf finansial dunia) pada dunia ekonomi modern dewasa ini, bahkan perekonomian modern tidak akan mungkin bisa eksis tanpa adanya pasar modal yang tangguh dan berdaya saing global serta terorganisir dengan baik.

Jakarta Islamic Index (JII) merupakan indeks saham yang mencerminkan keseluruhan saham syariah yang tercatat di BEI. Konstituen Jll terdiri dari tiga puluh saham yang merupakan saham-saham syariah paling likuid dan memiliki kapitalisasi pasar yang besar. BEI melakukan review JII setiap enam bulan yang disesuaikan dengan periode penerbitan Daftar Efek Syariah (DES) oleh Bapepam LK (sekarang OJK). Setelah dilakukan penyeleksian saham syariah oleh OJK yang dituangkan ke dalam Daftar Efek Syariah (DES), BEI melakukan proses seleksi lanjutan yang didasarkan kepada kinerja perdagangannya.

Dewan Syariah Nasional Majelis Ulama Indonesia no: 40/DSNMUI/X/2003, tentang Pasar Modal dan Pedoman Umum Penerapan Prinsip Syariah di Bidang Pasar Modal menyatakan bahwa pasar modal adalah kegiatan yang bersangkutan dengan penawaran umum dan perdagangan efek, perusahaan publik yang berkaitan dengan efek yang diterbitkannya, serta lembaga dan profesi yang berkaitan dengan efek. Penyusunan emiten yang termuat dalam Jakarta Islamic Index (JII) disusun berdasarkan prinsip yang berlandaskan syariah.

Indeks Harga Saham Gabungan (IHSG) adalah suatu angka yang digunakan untuk melihat perubahan mengenai harga dalam waktu dan tempat yang sama ataupun berlainan. Indeks adalah ukuran statistik yang biasanya digunakan menyatakan perubahan perbandingan nilai suatu variabel tunggal atau nilai sekelompok variabel. Perhitungan IHSG dilakukan setiap hari, yaitu setelah penutupan perdagangan setiap harinya. Dalam waktu dekat, diharapkan perhitungan IHSG dapat dilakukan beberapa kali atau bahkan dalam beberapa menit, hal ini dapat dilakukan setelah sistem perdagangan otomasi diimplementasikan dengan baik. Maka IHSG merupakan indeks yang digunakan untuk melihat perubahan harga saham secara keseluruhan di pasar. Kenaikan dan penurunan harga saham di bursa dapat dilihat dari penurunan dan kenaikan IHSG. Kenaikan IHSG tersebut menyatakan bahwa harga saham yang 
tercatat di bursa tersebut cenderung mengalami kenaikan lebih banyak dan lebih besar daripada harga saham yang mengalami penurunan. Demikian juga IHSG yang turun menyatakan penurunan harga cenderung lebih banyak dan lebih besar daripada harga saham yang mengalami kenaikan.

Indeks harga saham merupakan indikator utama yang menggambarkan pergerakan harga saham. Di pasar modal sebuah indeks diharapkan memiliki lima fungsi yaitu sebagai berikut:

1. Sebagai indikator trend pasar.

2. Sebagai idikator tingkat keuntungan.

3. Sebagai tolak ukuran (brandmark) kinerja suatu portofolio.

4. Memfasilitasi pembentukan portofolio dengan strategi pasif.

5. Memfasilitasi perkembangan produk derivatif.

Bangkitnya ekonomi Islam di Indonesia menjadi fenomena yang menarik terutama bagi penduduk Indonesia yang mayoritas beragama Islam. Praktek kegiatan ekonomi konvensional, khususnya dalam kegiatan pasar modal yang mengandung unsur spekulasi sebagai salah satu komponennya nampaknya masih menjadi hambatan psikologis bagi umat Islam untuk turut aktif dalam kegiatan investasi terutama di bidang pasar modal, sekalipun berlabel syariah.

Dalam konteks manajemen investasi, tingkat pengembalian (return) merupakan imbalan yang diperoleh dari investasi. Pengembalian ini dibedakan menjadi dua, yaitu pengembalian yang telah terjadi (actual return) yang dihitung berdasarkan data historis dan pengembalian yang diharapkan (expected return) akan diperoleh investor di masa depan.

Ada beberapa faktor yang dapat mempengaruhi return saham itu sendiri, beberapa faktor yang mempengaruhi harga atau return saham baik yang bersifat makro maupun mikro. $^{10}$

\section{Faktor makro}

a. Faktor Makro Ekonomi :

1) Inflasi

2) Suku Bunga

3) Kurs Valuta Asing

4) Tingkat pertumbuhan ekonomi

5) Harga bahan bakar minyak di pasar internasional

6) Indeks harga saham regional

b. Faktor Makro Non Ekonomi :

1) peristiwa politik domestic

2) Peristiwa sosial

3) Peristiwa politik Internasional

\section{Faktor Mikro Ekonomi}

yaitu faktor yang berasal dari dalam perusahaan. Informasi yang didapat dari kondisi intern perusahaan yang berupa informasi keuangan, informasi non keuangan. Beberapa

${ }^{10}$ Tjiptono Darmadji, Pasar Modal Di Indonesia (Jakarta: Salemba Empat, 2001).11. 
faktor yang mempengaruhi return saham terdapat 2 (dua) macam analisis untuk menentukan return saham secara garis besar, yaitu informasi fundamental dan informasi teknikal. Informasi fundamental diperoleh dari intern perusahaan meliputi deviden dan tingkat pertumbuhan penjualan perusahaan, karakteristik keuangan, ukuran perusahaan sedangkan informasi teknikal diperoleh di luar perusahaan seperti ekonomi, politik dan finansial.

Perubahan harga saham setiap hari perdagangan akan membentuk IHS angka indeks dibuat sedemikian rupa hingga dapat digunakan untuk mengukur kinerja saham yang dicatat di bursa efek, dimana return dan risiko pasar tersebut dihitung, Return portofolio diharapkan meningkat jika IHS cenderung meningkat, demikian sebaliknya return tersebut menurun jika IHS cenderung menurun. Dasar perhitungan indeks adalah jumlah nilai pasar dari total saham yang tercatat dengan metologi perhitungan menggunakan rata-rata tertimbang nilai pasar (market value weighted average index).

Perhitungan Indeks merepresentasikan pergerakan harga saham di pasar/bursa yang terjadi melalui sistem perdagangan lelang. Nilai Dasar akan disesuaikan secara cepat bila terjadi perubahan modal emiten atau terdapat faktor lain yang tidak terkait dengan harga saham. Penyesuaian akan dilakukan bila ada tambahan emiten baru, HMETD (right issue), partial/company listing, waran dan obligasi konversi demikian juga delisting. Dalam hal terjadi stock split, dividen saham atau saham bonus, Nilai Dasar tidak disesuaikan karena Nilai Pasar tidak terpengaruh.

Dalam indeks konvensional yang penting saham emiten yang terdaftar (listing) sudah sesuai aturan (legal) akibatnya bukanlah suatu persoalan jika ada emiten yang menjual sahamnya di bursa bergerak di sektor usaha yang bertentangan dengan Islam (bersifat merusak kehidupan masyarakat). ${ }^{11}$ Namun berbeda dengan indeks konvensional, dalam indeks syariah seluruh saham emiten yang terdaftar (listing) sudah sesuai aturan (legal) kemudian dilakukan screening dengan mempertimbangkan prinsip-prinsip syariah sehingga dapat mengurangi hal-hal merusak kehidupan yang dapat ditimbulkan dari indeks konvensional.

\section{B. Hasil Penelitian}

Perbandingan excess return JII dan excess return IHSG, dapat dilihat perbandingannya melalui Statistik data deskriptif kedua excess return tersebut. Data deskriptif tersebut dilihat dari mean kedua indeks, standar deviasi yang merupakan pengukuran risiko longgar, total return jangka panjang bagi kedua indeks yang diukur dengan jumlah semua return pada periode tersebut, nilai skewness yang menunjukkan kemenjuluran yang merupakan ukuran kemiringan, dan kurtosis yang memberikan informasi mengenai keruncingan dan digunakan untuk mengukur tingkat kepadatan sebaran.

Nilai Skewness yang kurang dari nol menunjukkan bahwa data memiliki distribusi yang miring ke kiri artinya data cenderung menumpuk pada nilai yang tinggi sedang untuk keruncingan pada nilai kurtosis menggambarkan fluktuasi dan stabilitas pada masing-masing

\footnotetext{
${ }^{11}$ Adrian Sutedi, Pasar Modal Syariah (Jakarta Timur: Sinar Grafika, 2011).56.
} 
indeks. Semakin tinggi nilai Kurtosis semakin tingginya keruncingan yang mengindikasikan semakin tingginya fluktuasi indeks dan semakin tidak stabilnya indeks tersebut.

Tabel

Desriptif Statistik

\begin{tabular}{|l|l|l|l|}
\hline & & IHSG & ISSI (JII) \\
\hline 1 & Mean & 0,002900 & 0.004183 \\
\hline 2 & Median & 0,004751 & 0.004769 \\
\hline 3 & Maximum & 0,030615 & 0.040823 \\
\hline 4 & Minimum & $-0,025019$ & -0.035350 \\
\hline 5 & Std. Dev & 0,010727 & 0.015422 \\
\hline 6 & Skewness & $-0,373230$ & -0.046787 \\
\hline 7 & Kurtosis & 1,720017 & 1.880840 \\
\hline 8 & Jarque-Bera & 4.925306 & 3.475204 \\
\hline 9 & Probability & 0,281744 & 0.324679 \\
\hline 10 & Observations & 72 & 72 \\
\hline
\end{tabular}

Data Olahan "Eviews 7

Berikut statistik deskriptif return indeks saham ditampilkan pada Tabel, jika dilihat dari mean kedua indeks, jelas bahwa rata-rata return dari JII lebih besar dari IHSG yaitu 0,002900 untuk IHSG, dan 0.004183 untuk JII. Begitu juga jika dilihat dari standar deviasi, yang merupakan pengukuran risiko longgar dan menunjukkan bahwa JII lebih berisiko dari pada IHSG yaitu 0.014403 untuk JII, dan 0,010727 untuk IHSG. Selanjutnya, total return jangka panjang bagi kedua indeks, yang diukur dengan jumlah semua kembali pada periode tersebut, menunjukkan bahwa JII memiliki nilai laba jangka panjang sebesar 0.040823 yang lebih tinggi daripada IHSG sebesar 0,030615.

Nilai Skewness JII dan IHSG menunjukkan nilai Skewness kurang dari nol yaitu 0.046787 untuk nilai skewness JII dan, nilai -0,373230 untuk nilai skewness IHSG artinya variable JII dan IHSG terdistribusi dengan baik.

Untuk nilai Kurtosis JII lebih besar yaitu 1.880840 daripada nilai Kurtosis IHSG 1,720017 , hal ini menandakan bahwa excess return Jll lebih berfluktuasi daripada excess return IHSG.

The Jarque-Bera (JB) uji normalitas signifikan pada $5 \%(0,05)$, dengan nilai pada IHSG 2,533510 sebesar dan JII sebesar 2.249838 menunjukkan bahwa hipotesis nol dari kenormalan data diterima.

Hasil deskripsi rata-rata menunjukan bahwa nilai return saham syariah yang diwakilkan oleh JII dan nilai return saham konvensional yang diwakilkan oleh IHSG menghasilkan ratarata hasil indeks JII jauh lebih baik dari return IHSG, dilihat dari hasil return dimana kedua indeks tersebut unggul dibidangnya masing masing seperti dalam indeks JII lebih baik dalam rata-rata return, dan tidak begitu berisiko, dalam hasil uji keruncingan IHSG memiliki nilai yang tidak terlalu berfluktuasi dan lebih stabil, sedang untuk indeks JII unggul pada nilai laba 
jangka panjangnya. Sehingga dapat disimpulkan hasil penelitian deskripsi menggambarkan indeks JII jauh lebih baik dibanding indeks IHSG.

\section{Analisis Hasil Penelitian}

IHSG - JII : 2.4975, dalam hasil ini menjelaskan bahwa nilai t-statistik lebih besar daripada nilai t table yaitu $2.4975>1.668$, artinya variable IHSG dalam jangka panjang mempengaruhi variabel JII. Dengan adanya hasil penelitian tersebut sesuai dengan teori menjelaskan indeks IHSG merupakan respresentasi indeks saham dan merupakan indeks yang digunakan untuk melihat perubahan harga saham secara keseluruhan dalam bursa efek Indonesia. JII termaksud indeks dalam bursa efek Indonesia oleh karna itu indeks IHSG mempunyai hubungan jangka panjang dengan indeks JII dimana kedua variable tersebut perubahan dalam hal return saham di pengaruhi oleh nilai dari kedua indeks tersebut, dimana nilai indeks tahun-tahun sebelumnya saling berkaitan mempengaruhi nilai indeks harga saham saat ini yang menghasilkan return saham setiap harinya.

JII - IHSG : 2.0258, dalam hasil ini menjelaskan bahwa nilai t-staistik lebih besar daripada nilai t table yaitu $2.0258>1.668$, artinya variable Jll dalam jangka panjang mempengaruhi variabel IHSG.Dengan adanya hasil penelitian tersebut sesuai dengan teori menjelaskan indeks JII merupakan salah satu indeks dalam Bursa Efek Indonesia, indeks saham yang merupakan indeks dari indeks IHSG.

\section{PENUTUP}

Dalam jangka pendek terdapat fenomena underpricing dan dalam jangka panjang terdapat penurunan kinerja (underperformance). Penentuan baik tidaknya kinerja saham, baik jangka pendek maupun jangka panjang dilihat dari besarnya return abnormal. Apabila return abnormal > 0 , menunjukkan kinerja yang outperformed (baik), sebaliknya apabila return abnormal $<0$ underperfomed (buruk).

Jika kita lihat hasil analisa jangka panjang maupun jangka pendek maka potensi pasar modal syariah dinilai baik dan masih akan mengalami pertumbuhan, hal ini terlihat dari hasil return indeks JII yang lebih baik dari indeks IHSG hal ini berhubungan dengan adanya kebijakan pemerintah yang membentuk Komite Nasional Keuangan Syariah (KNKS). Pasar modal syariah ini merupakan salah satu instrumen ekonomi yang dibutuhkan negara Indonesia dalam membantu pembangunan yang dilakukan oleh pemerintah ataupun swasta.

\section{DAFTARPUSTAKA}

Abdullah, Nur Atiqah, and Nur Adiana Hiau Abdullah, 'THE Performance of Malaysian Unit Trusts Investing in Domestic versus International Markets', Asian Academy of Management Journal of Accounting and Finance, 5 (2009), 77-100

Ajija, Sochrul R, Cara Cerdas Menguasai Eviews (Jakarta: Salemba Empat, 2011)

Ashraf, SH, and D Sharma, 'Performance Evaluation of Indian Equity Mutual Funds against Established Benchmarks Index', Int J Account Res, 2 (2014), 1-7 <https://doi.org/10.4172/ijar.1000113> 
Bauer, Rob, Rogér Otten, and Alireza Tourani Rad, 'Ethical Investing in Australia: Is There a Financial Penalty?', Pacific Basin Finance Journal, 14 (2006), 33-48 $<$ https://doi.org/10.1016/j.pacfin.2004.12.004>

Darmadji, Tjiptono, Pasar Modal Di Indonesia (Jakarta: Salemba Empat, 2001)

Fahmi, Irham, Teori Portofolio Dan Analisis Investing (Bandung: Alfabeta, 2009)

Hakim, Sam, and Manochehr Rashidian, 'Risk \& Return of Islamic Stock Market Indexes', 9th Economic Research Forum Annual Meetings Sharjah UAE, 2002, 26-28 <http://www.iefpedia.com/english/wp-content/uploads/2009/09/Risk-Return-of-IslamicStock-Market-Indexes.pdf>

Hussein, Khaled A., 'Ethical Investment: Empirical Evidence From FTSE Islamic Index', Islamic Economic Studies, 12 (2004), 21-40 <https://doi.org/10.3905/joi.2005.580557>

Kurniawan, Rizki Dwi, and Nadia Asandimitra, 'Analisis Perbandingan Kinerja Indeks Saham Syariah Dan Kinerja Indeks Saham Konvensional', Jurnal Ilmu Manajemen, 2 (4) (2014), 1356-66

Laksana, Vivi, 'PENGARUH FUND SIZE DAN FUND AGE TERHADAP KINERJA REKSA DANA SAHAM DI INDONESIA TAHUN 2009-2013', 2013, 1-21

Mansor, Fadillah, and M Ishaq Bhatti, 'Risk and Return Analysis on Performance of the Islamic Mutual Funds : Evidence from Malaysia', Global Economy and Finance Journal, 4 (2011), 1931

Putry, Galishia, Iman Sugema, and Deni Lubis, 'Analisis Perbandingan Excess Return Jakarta Islamic Index Dan Indeks Harga Saham Gabungan A Comparative Analysis of Jakarta Islamic Index' s and Indonesia Composite Index 's Excess Return', 2 (2014), 118-30

Samsul, Mohammad, Pasar Modal Dan Manajemen Portofolio (Surabaya: Erlangga, 2006)

Sutedi, Adrian, Pasar Modal Syariah (Jakarta Timur: Sinar Grafika, 2011)

Touiti, Mariem, 'Risk and Performance of Islamic Indexes during Subprime Crisis', 1-25

Utz, Sabastian, and Maximillian Wimmer, 'Are They Any Good at All? A Financial and Ethical Analysis of Socially Responsible Mutual Funds', Journal of Asset Management, 15 (2014), 72-82 <https://doi.org/10.1057/jam.2014.8> 